\title{
Strategi "Blantik" dalam Metode Pemasaran di Pasar Tradisional Hewan Dimoro Blitar
}

\author{
Rega Wulandari1 ${ }^{1}$, Nurul Laili Adha², Diki Setiawan \\ 1,2,3Fakultas Ekonomi, Universitas Islam Balitar Blitar \\ email: 1lailiadha028@gmail.com
}

\section{Kata kunci:}

Strategi, Blantik, Metode pemasaran, Pasar Tradisional hewan

\section{Keywords: \\ Strategy, Blantik, Marketing Method, Animal Traditional Market}

Wulandari, R., Adha, N. L., Setiawan, D. (2019). Strategi “Blantik" dalam Metode Pemasaran di Pasar Tradisional Hewan Dimoro Blitar. Akuntabilitas: Jurnal Ilmu-Ilmu Ekonomi, 12(1), 1-14. https://doi.org/10.35457/akuntabilitas.v1 $2 i 1.720$

\begin{abstract}
ABSTRAK
Pada masyarakat desa, istilah jasa perantara disebut dengan blantik. Blantik adalah jasa perantara yang masih tradisional. Peran blantik lebih banyak selesai pada tahap pertemuan penjual dan pembeli, termasuk didalamnya yang terdapat dalam perdanganan hewan ternak sapi maupun kambing di pasar-pasar hewan. Tujuan penelitian ini untuk mengetahui strategi "blantik" dalam metode pemasaran di pasar tradisional hewan Dimoro Blitar. Pendekatan yang digunakan dalam penelitian ini adalah pendekatan fenomenologi, berdasarkan pengalaman blantik di pasar tradisional di Kota Blitar pada tahun 2019 saat penelitian berlangsung. Metode yang diguinakan dalam penelitian ini adalah metode survey lapangan dan wawancara langsung dengan narasumber terkait dengan "blantik". Tujuan penelitian adalah dapat mengetahui bagaimana strategi "blantik" dalam memasarkan hewan ternakya di pasar hewan dan cara blantik mempengaruhi pelanggan atau konsumen agar bersedia membeli dagangannya. Dengan adanya penelitian ini menghasilkan 2 metode pemasaran yang berada di dalam dunia blantik di pasar Dimoro Blitar yaitu metode pemasaran "Ngompori" dan metode pemasara "powel". Metode pemasaran "Ngompori" merupakan cara menanas-manasi atau menghasut pelanggan agar membeli hewan yang dijual blantik walaupun dengan harga yang tinggi. Metode pemasaran "Powel" adalah metode yang digunakan blantik berdasarkan dari perubahan giginya pada hewan ternak.
\end{abstract}

\section{ABSTRACT}

In rural communities, the term intermediary services is called the blantik. Blantik is a traditional brokerage service. The role of the Blantik is more completed at the meeting stage of the seller and buyer, including those found in the handling of cattle and goats in animal markets. The purpose of this study is to find out the "blantik" strategy in the marketing method in the traditional market of Dimoro Blitar animals. The approach used in this study is a femenology approach based on the experience of the traditional market in Blitar City in 2019 when the research took place. The method used in this study is a field survey method and direct interviews with speakers related to the "blantik". The aim of the study was to be able to find out how the "blantik" strategy in marketing livestock in the animal market and how the blantik influenced customers or consumers to be willing to buy their wares. The existence of this research produces 2 marketing methods that are in the Atlantic world in the Dimoro Blitar market, namely the marketing method "Ngompori" and the method of marketing "powel". The marketing method "Ngompori" is a way of heating up or inciting customers to buy animals that are sold even though at high prices. The marketing method "Powel" is a method used by the blantik based on changes in its teeth in livestock. 


\section{PENDAHULUAN}

Pasar adalah sebagai tempat bertemunya pembeli dan penjual untuk melakukan transaksi jual-beli barang dan jasa. Interaksi yang terjadi antara penjual dan pembeli akan menentukan tingkat harga suatu barang atau jasa. Dalam pasar terdapat berbagai jenis aktivitas ekonomi, salah satunya yaitu jasa perantara. Jasa perantara sering muncul dalam pasar yaitu dalam kegiatan jual beli. Jasa perantara ini memiliki banyak istilah dalam lingkungan masyarakat, mulai dari makelar, calo, agen, hingga broker. Manfaat adanya jasa perantara ini adalah sebagai perantara untuk mempercepat terjadinya transaksi.

Salah satu jasa perantara yang lebih dikenal masyarakat khususnya masyarakat desa adalah "blantik". "Blantik". adalah suatu perkerjaan sebagai jasa perantara dalam penjualan hewan ternak. Blantik merupakan istilah yang berlaku untuk semua hewan ternak berkaki empat. Blantik memiliki pasaran dalam melakukan perdagangan yaitu misal selasa pahing atau kamis kliwon. Blantik identik dengan jasa perantara yang masih tradisional, dalam arti pelakunya masih perseorangan. Peran blantik pun lebih banyak selesai pada tahap pertemuan penjual dan pembeli, termasuk di dalamnya yang terjadi dalam perdagangan sapi maupun kambing di pasar-pasar hewan.

Strategi pemasaran merupakan salah suatu usaha yang dilakukan seseorang untuk mencapai tujuan yaitu mempertahankan kelangsungan untuk terus berkembang dan mendapatkan laba. selain itu tujuan pemasaran adalah menghasilkan pelanggan dan untuk mengetahui atau memahami pembeli dengan baik agar produk yang kita jual bisa terjual.

"Blantik" pun juga mempunyai berbagai usaha agar dapat mencapai tujuannya yaitu mendapatkan pelanggan dan menghasilkan keuntungan. Strategi pemasaran blantik seperti bekerja sama sesama blantik, memperbanyak relasi dan berkomunikasi yang baik dengan pelanggan, serta pengalaman dalam bisnis seorang blantik juga berpengaruh terhadap mendapatkan keuntungan yang akan diperoleh, karena berkaitan dengan tingkat kepercayaan seseorang yang ingin menggunakan jasa sang blantik. Keuntungan yang diperoleh pun beragam tergantung jenis hewan 
(kambing atau sapi). Tujuan ini bertujuan untuk mengetahui "Strategi "Blantik"

Dalam Metode Pemasaran Di Pasar Tradisional Hewan Dimoro Blitar"

Dalam penelitian ini mengambil relevansi antara beberapa penelitianpenelitian sebelumnya, diantaranya :

a. Berdasarkan penelitian Erni Wijayanti (2016) yang berjudul " Register Bahasa Mana Suka Blantik Sapi Di Mojokerto" menggunakan metode pengumpulan data observasi langsung dengan wawancara mendalam. Dapat disimpulkan bahwa karakteristik pemakian bahasa blantik sapi di Pasar Pon, daerah Kedondong Kabupaten Mojokerto tidak terlepas dari adanya dua wujud interaksi yaitu intrasksi internal (sesama komunitas blantik sapi) dan interaksi eksternal (anatar blantik sapi dengan pelanggan).

b. Berdasarkan penelitian dari Yitna Yuono (2016) yang berjudul “Transaksi Jual Beli Hewan Ternak Melalui Makelar Di Tinjau Dari Hukum Islam di Kabupaten Magelang". Penelitian ini didasarkan pada penelitian lapangan di Muntilan Kabupaten Magelang, jenis penelitian yang digunakan kualitatif yuridis sosiologis. Penelitian ini menyimpulkan bahwa dalam transaksi jual beli hewan terdapat akad ijaroh hal ini dimaksudkan untuk menghindari adanya riba.

c. Berdasarkan penelitian Erik Priyono Santoso dan Eka Fitasari (2016) yang berjudul "Analisis Agribisnis Ternak Kambing Dengan Pendekatan Market Atructure Conduct And Performance Di Kabupaten Ngawi" penelitian ini menggunakan metode kualitatif fenomenologi dengan metode pengumpulan data menggunakan interview dan observasi langsung. Dari penelitian ini dapat ditarik kesimpulan bahwa petani ternaknya hewan kepada blantik dadung yaitu petani ternak menghubungi blantik dadung, Blantik dadung akan melihat kambing. Setelah dilihat, petani ternak akan menawar dengan harga yang rendah dari yang ditawarkan petani ternak dan sesuai intruksi blantik yang mengetahui kondisi perkembangan informasi pasar.

\section{METODE PENELITIAN}

Penelitian ini dilaksanakan di pasar tradisional Dimoro Kota Blitar. Penelitian ini menggunakan penelitian kualitatif dengan pendekatan fenomenologi. Metode kualitatif merupakan suatu tindakan pengembalian data deskriptif berupa kata-kata 
tertulis dari kejadian dan perilaku tertentu (Moleong, 2000) Kualitatif terkait cara yang digunakan oleh peneliti dalam mendekati memahami, menggali, mengungkap fenomena tertentu dari informan penelitiannya. Dalam penelitian fenomenologi yang terpenting adalah wawancara mendalam terhadap "blantik" dengan cara mengambil informasi tentang strategi pemasaran blantik. Informan yang dipilih yaitu Bapak Rohani, Bapak Supin, Bapak Arifin, dan Bapak Iskandar.

Penelitian ini informan pertama bernama Bapak Rohani, yang berumur 51 tahun. Beliau tinggal di Ds. Sumber kec. Sanankulon kab. Blitar. Beliau adalah seorang blantik yang telah menekuni profesi blantik ini sejak 10 tahun terakhir. Kemudian informan yang kedua adalah Bapak Supin. Sekarang ini beliau berumur 58 tahun. Beliau tinnggal di Ds. Purworejo Kec. Wates Kab Blitar. Beliau merupakan seorang blantik yang terkenal sebagai blantik di desanya karena beliau telah menggeluti profesi sebagai balntik ini sudah lama . Tidak seperti blantik kebanyak, bapak supin hanya melakukan kegiatan blantik setiap tiba pasaran legi. Selanjutnya informan yang ketiga adalah Bapak Arifin 55 tahun. Sama seperti informan yang kedua bapak arifin ini juga telah menekuni profesi blantik ini selama 10 tahun. Yang bertempat tinggal di Ds. Kademangan. Informan yang terakhir yaitu Bapak Iskandar. Beliau sekarang ini berusia 54 tahun. Beliau telah berprofesi menjadi blantik sejak 5 tahun yang lalu. Beliau tinggal di Ds. Sumberasrib Kec. Nglegok Kab. Blitar. Beberapa informan tersebut dipilih karena telah lama berkecimpung dalam profesi blantik, sehingga diharapkan mampu memberikan informasi dan data terkait aktivitas blantik yang belum banyak diketahui oleh masyarakat.

Sumber data adalah sebuah tempat yang berisikan data-data yang diperlukan dan didapatkan dengan menggunakan cara-cara tertentu (Sutopo, 2006). Sumber data yang digunakan pada penelitian ini menggunakan data primer. Data primer merupakan data asli yang dikumpulkan oleh peneliti untuk menjawab masalah penelitiannya secara khusus. Survei dalam pemasaran data primer diperoleh secara langsung dari sumbernya yaitu dari blantiknya, sehingga peneliti merupakan "tangan pertama" yang memperoleh data tersebut.

Teknik pengumpulan data yang digunakan adalah observasi langsung, wawancara, Dokumentasi, dan pencatatan hasil pengumpulan data. Observasi 
langsung dilakukan di pasar Dimoro Blitar tepat pada hari pasaran legi karena dihari itu para blantik banyak yang berkumpul untuk melakukan kegitannya. Observasi langsung ditunjukkan untuk subjek dan objek penelitian yang sulit diprediksi karena situasi dilapangan tidak jarang berbeda dengan rencana awal. Penggunaan teknik observasi langsung memungkinkan bagi peneliti untuk mengumpulkan data mengenai perilaku dan kejadian secara detail, selain itu banyak juga data atau temuan temuan baru yang didapat. Dokumentasi didefinisikan dengan sebuah catatan kejadian yang telah terjadi (Sugiono, 2010). Dokumentasi yang diperoleh berupa gambar serta video yang menunjukkan alur dari blantik itu sendiri dalam melakukan kegiatan sehingga dapat dijadikan acuan dalam menarik kesimpulan. Dalam penelitian ini dokumentasi sangat penting sebab, dapat memberikan dukungan terhadap data dari wawancara dan obsrevasi sehingga data yang dihasilkan lebih lengkap serta akurat.

\section{PEMBAHASAN}

Strategi merupakan serangkaian rencana besar yang menggambarkan bagaimana sebuah perusahaan harus beroperasi untuk mencapai tujuannya, dan sekaligus dapat dibentuk straegi yang tertealisasi muncul dalam tanggapan terhadap strategi yang dapat dikembangkan melalui sebuah proses perumusan yang di ikuti oleh pelaksanaan (Usmara, 2008). Strategi adalah logika pemasaran dan berdasarkan itu unit bisnis diharapkan untuk mencapai sasaran-sasaran pemasaran, strategi pemasaran terdiri dari pengambilan keputusan tentang biaya pemasaran dari perusahaan (Klother, 2000). Strategi pemasaran yang digunakan oleh perusahaan merupakan hasil dipadukannya berbagai elemen pemasaran (Huda \& Martanti, 2018).

Strategi merupakan hal yang terpenting bagi perusahaan untuk mencapai tujuan perusahaan dalam jangka panjang. Perusahaan harus dapat menghadapi masalah yang datang dari dalam maupun luar perusahaan. Strategi dalam dunia bisnis sangat dibutuhkan sebab merupakan jalan utama untuk mencapai visi dan misi yang telah ditetapkan oleh perusahaan. Pemasaran merupakan sebagai suatu proses soal dan manajerial yang mencakup individu dan kelompok guna mendapatkan apa yang mereka butuhkan dan inginkan dengan cara menciptakan, 
menawarkan, dan mempertukarkan jasa yang bernilai dengan pihak lain (IBI-LSPP, 2015). Pemasaran berusaha menghasilkan laba dari jasa yang diciptakan sesuai dengan tujuan perusahaan.

Pemasaran adalah suatu sistem dari kegiatan yang bertujuan untuk sebagai perncanaan, penentuan harga, promosi dan pendistribusian barang dan jasa yang dilakukan perusahaan untuk mencapai tujuan yaitu mempertahankan kelangsungan untuk terus berkembang dan mendapatkan laba (Swastha dan Handoko, 2000). Pemasaran merupakan hal terpenting bagi keberhasilan suatu perusahaan. Jika pemasarannya bagus maka perusahaan tersebut akan dikenal oleh banyak masyarakat dan mendapatkan untung lebih banyak (Huda, Anam Miftakhul. Farida, 2018). Strategi Blantik merupakan salah satu bentuk strategi pemasaran yang sering dijumpai khususnya di pasar hewan tradisional. Dalam transaksinya startegi blantik melibatkan antara penjual (x) menggunakan jasa seorang blantik (y) dengan memberian rincian harga hewan milik penjual $(\mathrm{x})$ kemudian blantik tersebut menawarkan hewan milik penjual ke pembeli/rekan (z) dengan harga dan laba yang telah disepakati. Dengan kata lain pemilik hewan atau penjual tidak perlu mencari sendiri pembeli melainkan blantik lah yang bertugas mencari pembeli tersebut.

Strategi pemasaran adalah rencana yang menyeluruh, terpadu dan menyatu di bidang pemasaran, yang memberikan paduan tentang kegiatan yang akan dijalankan untuk dapat mencapainya tujuan pemasaran suatu perusahaan ( Sofjan, 2007). Berdasarkan pengertian di atas, maka dapat disimpulkan bahwa strategi pemasaran merupakan rangkaian suatu kegiatan yang terarah untuk mencapai sasaran dan dengan pola berpikir yang inovatif dan kreatif serta aturan yang memberi arah kepada usaha-usaha pemasaran barang dan jasa untuk memperoleh suatu hasil yang optimal. Strategi blantik merupakan salah satu bentuk strategi pemasaran yang sering digunakan oleh masyarakat umumnya di pedesaan untuk menjual hewan ternak baik sapi maupun kambing yang dilakukan dengan menawarkan kepada masyarakat atau pun calon pembeli agar besedia membeli barang dagangan yang dijual. 
Hasil penelitian menunjukkan bahwa "Blantik" memiliki alur atau model transaksi yang sedikit berbeda dari transaksi jual-beli pada umumnya. Terdapat tiga pihak yakni penjual, blantik dan pembeli. Blantik sendiri memiliki teknis pelaksanaan transaksinya sendiri seperti yang diungkapkan Bapak Arifin sebagai blantik kambing di Pasar Hewan Tradisional di kota Blitar.

“...Pertama lihat kambingnya, kedua tawar menawar ya kalau dagang itu gak bisa langsung mengambil saya harus laba sekian nggak bisa. Bisa untung bisa rugi"

Dari penjelasan diatas dapat diketahui pemilihan kambing sangat berpengaruh dalam penentuan harga dan laba yang ditentukan. Hasil penelitian menunjukan bahwa "Blantik" adalah jasa perantara yang masih tradisional, yang biasanya berada di daerah pedesaan atau di kota terpencil yang tugasnya menjual belikan dagangan orang lain tanpa harus mengeluarkan modal sama sekali atau biasanya dapat disebut juga dengan makelar. Peran blantik pun lebih banyak selesai pada tahap pertemuan penjual dan pembeli, termasuk didalamnya yang terjadi dalam perdagangan hewan ternak di pasar hewan tradisional seperti sapi dan kambing.

Dalam pembentukan harga, setiap blantik berbeda-beda dapat diketahui dari Bapak Supin ketika ditanyakan mengenai harga kambing di pasar hewan Demoro Blitar.

"... ben blantik lek nawakne wedus orak podo, kadang yo enek seng larange nemen, kadang yo gor njukuk bati titik nduk" [setiap blantik mewanarkan harga kambing tidak sama, kadang ada yang menawarkan dengan harga yang tinggi, kadang hanya mengambil untung sedikit nak]

Dari penjelasan diatas dapat dikatakan bahwa harga di pasar hewan seperti kambing ditetapkan oleh masing-masing blantik. Struktur pasar hewan ini mendekati pasar jenis monopolistic dimana penjual menentukan harga barangnya masingmasing. Memang setelah ditinjau kembali, harga hewan dapat berbeda dari blantik satu ke blantik yang lain, meskipun demikian hewan tersebut tetap laku karena terdapat pembeli selalu membeli di blantik tersebut (langganan), serta adanya strategi khusus yang membedakan blantik satu dengan blantik yang lain yang akan di bahas lebih lanjut. 
Selain itu penelitian ini menunjukkan bahwa sebelum menjual belikan hewan ternaknya seorang blantik negoisasi dengan juragan yang mempunyai hewan ternak tersebut untuk menetapkan harga jualnya. Seperti yang yang diungkapkan oleh Bapak Rohani sebagai salah satu blantik di pasar hewan Dimoro Blitar.

"Aku biasane sak urong e ngedolne wedus iki aku omong-omongan disek kro seng duwe weduse disek, piro regone terus aku engko oleh bati orak teko uwong e. Lek mari omong-omongan aku maleh eroh kudu ngedolne wedus kuwi sak piro" [saya biasanya sebelum menjual belikan kambing ini saya bernegoisasi dulu dengan pemilik kambing terlebih dahulu, berapa harganya setelah itu saya nanti dapat bagian atau tidak. Setelah bernegoisasi saya menjadi tau saya harus menjual dengan harga berapa.

Dari penjabaran diatas dapat dibuat model transaksi sebagai berikut:

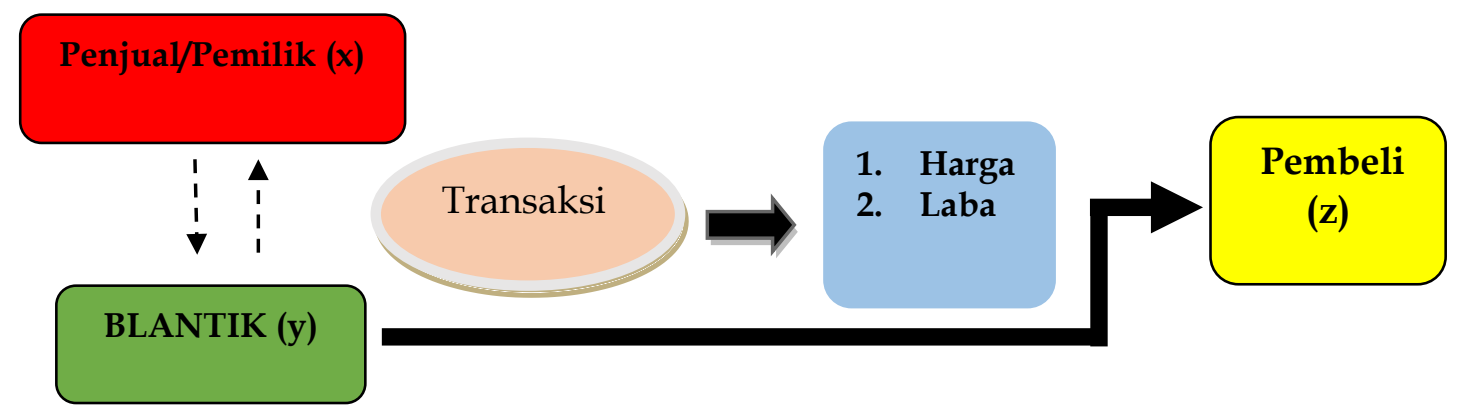

\section{Gambar 1 Model Transaksi Pasar}

Dari penjelasan diatas dapat diketahui bahwa seorang blantik (y) sebelum menjualkan hewan dagangannya membutuhkan negoisasi dengan pemilik hewannya (x), agar mengetahui berapa keuntungan yang didapat setelah menjualkan hewan ternaknya kepada pembeli (z) untuk mengambil keuntungan.

\section{Metode Pemasaran "Ngompori".}

Dari hasil penelitian menunjukkan bahwa di pasar Dimoro tidak buka setiap hari melainkan hanya buka hari legi dan pon menurut tanggalan jawa, jadi untuk harinya tidak pasti. Seperti yang diungkapkan oleh bapak supin selaku blantik di pasar Dimoro :

"Dimoro pasaran dino legi kro pon, lek pas rame ne dino legi. Bedane ngene carane antara seng teko pon lebih titik daripda seng legi. Kalau pon hanya terbatas teko sekeliling kabupaten saja, kalau hari legi ada yang dari Jakarta dan Surabaya" [ Dimoro pasaran hari legi dan pon, kalau pas rame hari legi. Bedanya gini caranya antara pembeli yang datang pon lebih sedikit dari pada yang legi. Kalau pon hanya terbatas dari sekeliling kabupaten saja, kalau hari legi ada dari Jakarta dan Surabaya ] 
Dari penjelasan diatas dapat diketahui bahwa pasar Dimoro buka hari pon dan legi atau seminggu buka 2 kali dan harinya tidak pasti. Selain itu ternyata yang datang tidak hanya masyarakat Kabupaten Blitar saja, melainkan kota-kota lainnya juga datang di pasar ini termasuk dari Jakarta dan Surabaya.

Selain itu, jika kita ke pasar Dimoro kita akan melihat sesuatu yang unik yaitu jika seorang molang memakai topi koboy, maka blantik hanya memakai laker sedang. Seperti yang diungkapkan oleh bapak Supin sebagai salah satu blantik di pasar hewan:

"Ciri khas teko blantik kuwi lek molang gae topi koboy, maka blantik gae laker sedang. Kadang blantik kuwi pacak ane rapi nglebihi seng nduwe barang" [ ciri khas dari blantik itu kalau molang memakai topi koboy, kalau blantik memakai laker sedang. Kadang blantik itu berpenampilan melebihi yang punya barang.]

Dari penjelasan diatas dapat diketahui bahwa di pasar hewan Dimoro memiliki keunikan yang terlihat dari molang atau yang punya barang dan dari blantik juga. Selain itu ternyata seorang blantik pun dalam hal berpenampilan juga rapi agar pembeli tidak bisa membedakan antara blantik atau bukan.

Dari hasil penelitian menunjukkan bahwa blantik merupakan jasa perantara antara yang punya barang dengan pembeli. Selain itu seorang blantik tidak mengeluarkan modal sama sekali. Seperti yang diungkapkan oleh Bapak Rohani :

"Pokok lek blantik kuwi koyok perantara antara molang utowo seng nduwe barang kuwi karo pembeli tanpa kudu ngetokne duwet blas. Lek molang kuwi seng nduwe barang, deke kan seng tuku mestine kan ngetokne doal. Seperti saya pedangan sapi kan tetapi enek pembeli seng pengen sapi jantan tibak e aku gak nduwe sapi seng dipengeni seng arep nuku. Terus tak golekne neng pedangang liyo kuwi iso dikatakan blantik ngarai aku mesti mencari untiung kan tanpa kudu ngetokne duwet gor dadi perantara tok" [ Pokok kalau blantik itu seperti perantara antara molang atau yang punya barang tersebut dengan pembeli tanpa harus mengeluarkan modal sama sekali. Kalau molang itu yang punya barangnya, diakan membeli dan pastinya mengeluarkan modal. kayak saya pedangang sapi kan tetapi ada pembeli yang menginginkan sapi jantan dan ternyata saya tidak mempunyai sapi yang di inginkan si pembeli, dan saya carikan sapi tersebut ke pedangang lain itu bisa dikatakan blantik karena saya pasti akan mencari untung kan tanpa harus mengelurkan uang, hanya menjadi perantara saja.

Selain itu Bapak Supin juga mengungkapkan bahwa :

"Blantik kuwi gor modal omong tok, kro kudu iso moco opo ndelok karakter pembeli kuwi koyok opo seng wajah begini uwong e biasane koyo ngene, kadang-kadang orang begini lek dikasih omongan banyak gak demen dadi yo kudu pinter-pinter ngetokne omongan kro kudu pinter ngrayu. Lek pinter nngrayu kro dijak omong ae bene engko lek pas arep nawar dengan harga murah maleh lali, opo eneh seng wajah-wajah judes 
kuwi kuncine kudu dibombong dengan kata-kata seng manis" [blantik kuwi hanya modal bicara saja dan harus bisa membaca atau mengetahui karakter pembeli itu seperti apa kayak orang begini wajah begini orangnya biasanya begini, kadang-kadang orang kalau dikasih omongan banyak tidak suka jadi harus pandai-pandai menmgeluarkan kata-kata dan harus pintar mengambil hati. Kalau pintar mengambil hati sama diajak bicara terus agar nanti mau menawar dengan harga murah jadi lupa, apalagi kalau yang wajah-wajah judes harus bisa dipuji-puji dengan kata-kata yang manis].

Dari penjelasan diatas dapat diketahui bahwa blantik merupakan jasa perantara antara yang punya barang atau disebut dengan molang dengan pembeli. blantik tidak memerlukan modal sama sekali, modal utamanya adalah pintar berbicara untuk mempengaruhi pembeli agar membeli dagangannya.

Selain itu untuk mendapatkan pelanggan seorang blantik harus bisa membaca atau mengetahui karakter si pembeli, agar saat bertransaksi seorang blantik bisa lebih muda mempengaruhi si calon pembeli agar dapat membeli danganannya. Dan seorang blantik harus bisa mengambil hati si calon pembeli, saat berbicara seorang blantik harus bisa dibawahnya si pembeli. Selain itu saat kita berada de pasar Dimoro kita akan dapat mengetahui bahwa selain harus pintar berbicara, seorang blantik mempunyai cara saat memasarkan dagangannya. Seperti yang diungkapkan oleh bapak Arifin sebagai salah satu blantik di pasar Dimoro :

"Kadang blantik kudu pinter lek pas oleh pembeli langsung dijak neng pinggir opo golek tempat seng sepi bene oarak diganggu karo blantik liyo. Ngarai lek wes kadung kelebonan blantik liyo kuwii engko biasane ngrusak, ngekeki rego neng ngisore regone aku ngedol" [terkadang blantik harus pintar waktu dapat pembeli biasanya langsuing diajak ke pinggir pasar atau mencari tempat yang sepi agar tidak diganggu oleh blantik lainnya. Karena jika sudah di masuki blantik lain itu nanti biasanya merusak, dengan cara memberi harga dibawah harga saya menjual].

Dari penjelasan diatas dapat diketahui bahwa blantik mempunyai berbagai cara agar mendapatkan pembeli. Seperti pada saat mendapatkan pembeli si blantik akan menjauhkan calon pembeli tersebut dari blantik lain, agar tidak di ganggu oleh blantik yang lainnya. Hasil penelitian menunjukkan bahwa konsep "Ngompori" adalah suatu cara memanas-manasi seseorang agar mengikuti apa yang kita inginkan atau terpincut dengan yang kita mau. Konsep "Ngompori" adalah salah satu strategi blantik untuk mendapatkan pembeli agar membeli barang dangannya. Seperti yang diungkapkan oleh Bapak Supin selaku sebagai blantik di pasar Dimoro : 
"Blantik kuwi mesti nduwe kelompok emboh kuwi 4 opo paling minimal 2 uwong, kuwi enek pembagian tugas, lek seng 2 uwong ki biasane enek seng bagian harga kro seng bagian ngompori, ngompori kuwi biasane seng nyamar dadi pembeli" [blantik itu pasti mempunyai kelompok entah itu 4 atau paling minimal 2 orang, itu ada pembagian tugas, kalau yang dua orang itu biasanya ada yang pembagian harga dan ada yang bagian manas-manasi, manas-manasi itu biasanya menyamar jadi pembeli]

Dari penjelasan diatas dapat diketahui bahwa seorang blantik tidak dapat berjalan sendiri mereka mempunyai kelompok entah itu 4 orang maupun 2 orang yang didalamnya mempunyai peran atau tugas masing-masing, seperti ada yang bagian "ngompori" atau bertugas sebagai memanas-manasi pelanggan dengan perpura-pura menjadi pembeli.

Selain itu hasil penelitian menunjukkan bahwa blantik juga mempunyai cara untuk mendapatkan pelanggan yaitu seperti yang diutarakan oleh Bapak Rohani sebagai berikut:

"Kadang blantik kuwi butuhne blantik liyo digae pura-pura nuku wedus dengan harga seng paling duwur, bene seng arep nuku wedus kuwi orak ngenyang rego seng murah" [terkadang blantik membutuhkan blantik lain untuk berpura-pura membeli kambing dengan harga yang tinggi, agar yang mau membeli kambing tersebut tidak menawar dengan harga yang murah].

Dari penjelasan diatas dapat dikatakan bahwa seorang blantik dalam menjualkan dagangannya terkadang bermain pintar yaitu dengan memanfaatkan blantik lain untuk berpura-pura menjadi pembeli agar yang mau membeli tidak menawar dengan harga yang rendah.

Dari dua narasumber tersebut sudah jelas bahwa "Ngompori" merupakan salah satu cara blantik yang paling pintar untuk mendapatkan pembeli yaitu dengan cara bekerja sama antara blantik satu dengan yang lain. Selain itu, ada pembagian kerja yang begitu rapi. Sehingga pada saat bertransaksi sudah mengetahui tugasnya masing-masing. Selain itu "Ngompori" merupakan cara yang paling sering digunakan para blantik karena dengan mengompori membuat pembeli menjadi tertantang untuk membeli.

Metode "Ngompori" sering digunakan oleh para blantik di pasar-pasar tradisional, bisa dilihat pada waktu saat kita datang ke pasar untuk membeli kambing atau sapi pasti kita akan langsung disambut oleh blantik yang menawarkan 
dagangannya, pada saat kita negoisasi maka anggota blantik lain akan datang ke kita dengan cara memuji yang bagus tentang hewan yang kita tawar seperti hewan ini gemuk, hewan ini calon yang bagus, hewan ini harganya murh, dll. Seorang blantik yang tugasnya "Ngompori" akan membuat calon pembeli kebingungan, jika sudah kebingungan maka pembeli akan membeli hewan tersebut walau terkadang dengan harga yang tinggi.

\section{Model Pemasaran Blantik "Powel"}

Dalam melakukan penjualan, seorang blantik juga harus memperhatikan kualitas dari barang yang dijualnya agar ketika melakukan pemasaran barang tesebut berjalan efektif. Dalam kualitas dari hewan ternak bisa ditentukan dengan istilah "powel". "Powel' merupakan suatu ciri khusus yang dimiliki hewan ternak baik sapi maupun kambing. Kata "powel" yang didefinisikan oleh bapak iskandar adalah sebagi berikut ini :

"Powel itu ganti gigi. Jadi gigi dari gigi yang muda mungkin gigi kambing yang kecil-kecil itu masih muda giginya pasti kecil-kecil kalau sudah ganti itu namanya powel. Jadi pergantian gigi itu yang dinamakan dengan powel...."

Dari penjelasan diatas, definisi powel dalam blantik adalah proses ganti gigi hewan ternak dari yang awalnya kecil-kecil akan berganti menjadi besar-besar. Perubahan itulah yang dimaksud dengan "powel. Hewan ternak yang sudah "powel" juga memiliki ciri-ciri pada tubuhnya. Contohnya pada kambing. Kambing yang sudah "powel" ketika sebelum disembelih kelihatan gemuk, maka ketika disembelih juga akan benar- benar gemuk atau berdaging berbeda dengan kambing yang belum "powel" ketika sebelum disembelih kelihatan gemuk maka jika nantinya disembelih akan sedikit dagingnya atau tidak berdaging.

"Powel" juga berpengaruh didalam penjualan hewan ternak yang dilakukan blantik. Biasanya blantik akan lebih mendapatkan banyak keuntungan yang diperoleh dari penjualan hewan ternak yang sudah "powel" ini, karena hewan ternak yang "powel" juga cenderung banyak yang mencarinya. Dengan hewan ternak yang sudah "powel" blantik lebih banyak dicari para calon pembeli yang akan digunakan pada acara-acara khusus seperti contohnya : pada acara aqiqah yang diharuskan menggunakan kambing yang sudah "powel" dan pada acara besar keagamaan (hari raya Idul Adha) yang juga mengaharuskan kambing yang digunakan tersebut adalah 
kambing yang sudah "powel" tersebut. Hal ini yang diungkapkan oleh bapak iskandar :

"....jadi kalau kambing itu misalkan powel biasanya diminati orang untuk disembelih, misalkan untuk aqiqah dan kurban itu dipastikan kambing yang sudah powel karena apa ? karena untuk memenuhi syarat-syarat tertentu tersebut."

Maka, hewan ternak yang sudah powel akan cenderung banyak diminati daripada hewan yang belum powel, meskipun dalam kehidupan sehari-sehari masih banyak calon pembeli yang mencari kambing belum powel untuk sebagai "openopen" kalau orang jawa menyebutnya atau bahasa Indonesia "hewan ternak". Terdapat selisih keuntungan yang diperoleh oleh seroang blantik ketika menjualkan hewan ternak yang sudah powel dengan yang belum powel.

\section{KESIMPULAN}

Strategi "blantik" merupakan salah satu bentuk strategi pemasaran yang sering digunakan oleh masyarakat umumnya di pedesaan. Blantik pun memiliki alur atau model transaksi yang sedikit berbeda dari transaksi jual-beli pada umumnya. Terdapat tiga pihak yakni penjual, blantik dan pembeli. Terkadang seorang blantik tidak dapat berjalan sendiri dalam mempengaruhi pelanggan agar membeli hewan ternaknya, mereka membutuhkan blantik lain dalam mempengaruhi pelanggannya agar hewan ternaknya terjual atau biasanya disebut "Ngompori". Metode "Ngompori" merupakan suatu cara memanas-manasi seseorang agar mengikuti apa yang kita inginkan atau terpincut dengan yang kita mau. Konsep "Ngompori" adalah salah satu strategi blantik untuk mendapatkan pembeli agar membeli barang dangannya. Dalam memilih kualitas hewan ternak yang akan dijual oleh seorang blantik maka terdapat istilah yang sering dipakai oleh blantik adalah "powel. Definisi powel dalam blantik adalah proses ganti gigi hewan ternak dari yang awalnya kecil-kecil akan berganti menjadi besar-besar. Perubahan itulah yang dimaksud dengan "powel. Hewan ternak yang sudah powel akan cenderung lebih mudah dijual oleh blantik karena cenderung sering yang membutuhkannya, contohnya utnuk acara aqiqah serta acara kurban pada hari raya Idul Adha. Blantik juga akan mendapatkan perbedaan laba yang diperoleh dari penjualan hewan ternak yang sudah powel dengan hewan yang belum powel. 


\section{DAFTAR PUSTAKA}

Assauri, Sofjan. (2007). Manajemen Pemasaran. Jakarta: Raja Grafindo

Basu Swastha dan T. Hani Handoko. (2000). Manajemen Pemasaran (Analisis Perilaku Konsumen). Yogyakarta: BPFE UGM.

E. P. Santoso dan E. Lestari. (2009). Analisis Agribisnis Ternak Kambing Dengan Pendekatan Market Structure Conduct And Performance. Ngawi: Universitas Tribuana Tunggadewi.

Huda, Anam Miftakhul. Farida, N. (2018). Pengantar Ekonomi Mikro (Pertama). Pekalongan: NEM.

Huda, A. M., \& Martanti, D. E. (2018). Pengantar Manajemen Strategik 1. (J. Press, Ed.) (1st ed.). Bali: http:/ / books.jayapanguspress.org/index.php/publisher/article/view/18/18. Retrieved from http://books.jayapangusCNpress.org/index.php/publisher/article/view/18 /18

IBI-LSPP. (2015). Strategi Bisnis Bank Syariah. Jakarta: Gramedia Pustaka Utama.

Klother, Philip. (2000). Marketing Management. Edisi Milenium. Prentice Hall Intl: New Jersy.

Lexy. J. Moleong. (2000). Metodologi Penelitian Kualiatatif. Bandung: PT. Remaja Rosdakarya.

Sugiyono. (2010). Metode Penelitian Pendidikan Pendekatan kuantitatif, Kualitatif, dan REd. Bandung: Alfabeta.

Sutopo. (2006). Metodologi Penelitian Kualitatif. Surakarta: Universitas Sebelas Maret Surakarta.

Usmara, Usi. (2008). Pemikiran Kreatif Pemasaran. Yogyakarta: Amara Book.

Wijayanti, Erni. (2016). Register Bahasa Mana Suka Blantik Sapi. Mojoketo: SMP Negeri 1 Sooko Mojokerto.

Yuono, Yitna. (2016). Transaksi Jual Beli Hewan Ternak Melalui Makelar Ditinjau Dari Hukum Islam. Magelang: IAIN Salatiga. 